UDC: 504.2:614.82 614.841.42:630

COBISS.SR-ID: 211610380

Original research paper

Acta Agriculturae Serbica, Vol. XIX, 37 (2014); 71-81



\title{
Forest fires are a risk factor for plant species
}

\author{
Stanimir Živanović \\ Department of Emergency Management, Kneza Miloša 103, 11000 Belgrade, \\ Serbia
}

\begin{abstract}
The growth, development and the prevalence area of plant species are determined by a variety of influences. Plants are increasingly exposed to the different stress factors. Fires in nature can completely destroy the whole forest complex habitats with great biological diversity of many species in a short period of time. This study deals with the effects of a fire, such as heat, to the plants. After the fire, the environment is being changed and some species in areas affected by the fire will appear only after the fire, some species that had existed before the fire, will be developed in accordance with the new conditions, and some species will disappear after the fire.

The aim of the study was to assess the sustainability of the natural vegetation in fire conditions, which is important for natural regeneration and nursery production. Fire temperatures cause irreparable damage of the plant functions or of the plant organs. In the analysis of the plant species the frequency of the fire is often more important than the type and intensity of the fire. Regarding possible long fire season in Serbia, as well as the presented statistics data about the number of fires and burnt areas, it can be concluded that there is an evident risk of plant species of fire, which are more common in this region.
\end{abstract}

Key words: forest fire, endangering the species, environment.

Received: 23. 12. 2013. / Accepted: 15. 09. 2014. 


\section{Introduction}

Matter constantly circulates through environmental community, and on this circular process, with its primary stages and the aging of organic matter and its mineralization, is based the whole dynamics of the community life. Any disturbance in this circular process affects the normal flow of matter circulation and changes it in a certain direction .

The prevalence of plant species in nature is determined by their temperature resistance and by their requirements for temperature. Different plant species, as well as various organs of the same plant or even tissues, have particular requirements for a temperature (Stevanović et al. 2001).

These requirements are changing to the some extent depending the period of growth and development of plants. Plant tissue does not tolerate temperatures above $45^{\circ} \mathrm{C}$. During the evolution, certain plant species, have developed the socalled CAM (Crassulacean acid metabolism) photosynthesis type by which they are adapted to the high temperatures conditions up to $65^{\circ} \mathrm{C}$. The temperature maximum for the majority of the plants is between $45-55^{\circ} \mathrm{C}$ (Borges et al. 1993, Cochrane 2009). In this area, the temperature optimum for the majority of the plants for growth and development, ranges from 15 to $30^{\circ} \mathrm{C}$.

A particular type of risk from high temperatures and overheating of plants and vegetation is a fire (Cochrane 2009). It is an important environmental factor in certain areas (Australia, California, Mediterranean). It is necessary to understand how fire affects plant species, and how they behave during the restoration of vegetation. High temperatures during fires can directly damage plant tissue during combustion and indirectly damage plant physiological processes through radiant heating (Levitt 1972). There are many studies that analyze the influence of heat on various types of vegetation (Brown et al . 2000, Schwilk et al. 2001, Kane et al. 2008), as well as on the organs of the plant (Keeley, 1987., Reyes et al. 1994., Reyes et al. 1995., Rabanal et al. 1995, Escudero, 1997., Pausas, 1997., Reyes et al. 1997., Valbuena et al.1998, Nunez et al. 2000., Reyes et al. 2000, Reyes et al. 2006., Kane, 2008).

According to the National Forest Inventory of the Republic of Serbia (2009), the percentage of forest coverage is $29.1 \%$ (or $34.0 \%$, including shrubs and bushes). In recent years, on the territory of Serbia, the occurrence of forest fires is becoming more frequent, which severely endanger the safety of people and material goods (Sekulić et al. 2012). Aleksić et al (2009) in their study stated that wildfires are the major economic problems in forestry of Serbia. The data indicate that often, the fire affected area are habitats of rare and endangered plant species. Sekulić et al (2012) in their study reported that fires can be a serious threat to ecosystems and individual species. From the total number of relict, endemic, rare and threatened species of forest trees and shrubs, under the 
fire risk are 12 threatened, 5 rare, relict 9, and 6 endemic risk plant species (Banković et al. 2009).

The aim of the research presented in this Study was to determine the impact of fire on the stability of plant communities in nature.

\section{Materials and methods}

Serbia is located in Southeastern Europe between $18^{\circ} 39^{\prime}$ and $23^{\circ} 01^{\prime}$ of east latitude and $41^{\circ} 51^{\prime}$ and $46^{\circ} 11^{\prime}$ north longitude. The Republic of Serbia covers $88361 \mathrm{~km}^{2}$ with an average altitude of $470 \mathrm{~m}$. The forest coverage in Serbia is around $29.1 \%$ of the territory, with dominant deciduous species. Winters in Serbia are short and cold, and summers are warm.

For this analysis, the statistical data about the registered number of fires in the open air in the Republic of Serbia were used. Risk assessment of plant species of fire in nature has been done on the dynamics of fire occurrence in the period 2004 to 2011. After processing the statistical data of the registered number of fires, it is possible its use them in defining fire risk on plant species

\section{Results and Discussion}

\section{Fire effects on plants}

The physiological processes in plants depend on the kinetics of enzymatic reactions. The mobility of water and solutes through the plant is indirectly dependent on the temperature. Each habitat is characterized by specific characteristics and dynamics of soil and air temperature. This process is constantly changing during the growth and development of plants, but also in the course of one day. Requests for warmth are very different. At the optimal temperature, vital functions of plants are being carried out at high speed. Changes of the temperature values from the optimum temperature to critical result in irreparable damage of the functions or of the plant organs. Extremely high temperatures that occur during a fire can completely destroy over ground, and underground plant parts often, (Mihajlović et al. 2014). The reaction of some kind of fire is different: some species in areas affected by fire will appear only after the fire, some of which existed before the fire, will be developed in accordance with the newly conditions, and some will disappear after the fire (Chandler et al. 1983., Malanson 1997). According to Martin (1963) mortality of the plants and seeds of the fire, depend on the duration of exposure to lethal temperatures. Mortality can occur with a short exposure to high temperatures (Martin 1963), while the mortality rate at lower temperatures is often caused by a longer period of exposure. 
Combustion of biomass releases high temperatures of $1000^{\circ} \mathrm{C}$ and radiation in the environment combustible materials in nature, can be classified in three groups: large combustible materials, small combustible materials and green fuel material.

Large combustible material comprises multiple layers of mixed logs, thick branches, tree stumps, tree trunks and dry material of various sizes. The characteristics of this material is that it can rarely start to burn without the combustion of small combustible materials, which previously dries it. Burning characteristic of large combustible material is that it can burn for a long time, sometimes for several days (Veselinović et al.2007), which makes it difficult to extinguish and enables the appearance of new fires if the fire affected area is not controlled good enough.. Small fuel material is usually found on the ground and it consists of dry grass, dry brush, fallen bark, dead leaves and needles, small branches, pine cones, litter, etc.. The characteristic of this material is a low level of humidity and high flammability (Veselinović et al.2007). Fire of small retardant materials is rapidly expanding on the surface. The fire can be spread throughout the organic mass of biocenosis, although, the whole forest burns rarely. In the presence of wind, surface fire in the conifer plantations with tall trees can be developed into a high fire.

Green combustible material, in volume and quantity, is the most common and it consists of the vegetation, green grass, young plants and trees of all ages and sizes. Due to the high moisture content, green material is not flammable, but the incoming fire dries it and it burns quickly after the contact with the flame. Due to the high volatile oil, certain types of plants (needles of pine and spruce) burn easily and quickly in the contact with the flame (Veselinović et al.2007). Green needles are very sensitive to temperatures over $50^{\circ} \mathrm{C}$ so that the fire is quickly spread. A temperature of $62.7^{\circ} \mathrm{C}$ is high enough to completely destroy pines for a few seconds (Veselinović et al.2007).

The moisture content of the plant has a significant role in determining the risk of fire. Moisture content in plants varies during the year. The highest values are in a period of growth and development of plants, and the lowest is the period of rest. In general, hardwood tend to be disadvantaged throughout the growing season. Softwoods are more vulnerable to a fire in the spring when the moisture content is the lowest in old leaves, which increases the overall flammability.

Serbia is a country with rich floristic 3526 taxons where the plants vascular flora are listed in 141 family and 766 genera. According to the available data in the Republic of Serbia there are over 300 threatened plant species (Stevanović et al. 1999). Due to unfavorable environmental conditions several plant and animal species has disappeared for the past 100 years. Forest ecosystems in Serbia consist of 250 indigenous tree species (Stevanović 1999), which according to geographical and floral elements belong to the middle - European, Pontian and Mediterranean element . 
In Serbia, under the protection is $6.19 \%$ of the territory or 547 176ha (2007) and this share of protected areas, classifies Serbia among the countries with medium level of protection. According to the Regulation on proclamation and protection of protected and strictly protected wild species of plants, animals and fungi (2010), 629 species of plants are strictly protected and 533 species are protected plants. Within the forest resources of special importance is the presence of 88 wild fruit tree species in 18 genera. Special value and significance of the flora of Serbia are relict, endemic, rare and threatened species of forest trees and shrubs. Out of the total number (38) species, the analysis shows that 12 rare and endangered, 5 are rare, 9 relict, 6 are endemic and 6 species are at the risk (Banković et al. 2009).

The underground fires occur less often compared to the low and high - fires, and so the damage from these fires are significantly smaller. The most common are ground fires, which cover large areas of forest and forest land. Damage of forests caused by ground fires depends on the intensity of burning, tree species and the frequency of fires. Trees that survive the fire have the "wound" caused by fire. Superficial tissues and cambium of the trees are damaged and that allows easy penetration of various pathogens and insects. Temperatures above $54^{\circ} \mathrm{C}$ kill cambium cells in the injured back to the roots which may later affect the drying of trees, although the fire was extinguished long ago. Because of the resin in the wood and needles, conifers are more at risk of fire from sawmills. Due to the high content of resins and dry branches, the most vulnerable of the fire is white pine and spruce . In principle, light areas provide a rich development of land grasses cover and weeds being more vulnerable of ground fire. Areas in shadows are less_affected by the fire. Trees with thick bark are more resistant to fire than those with smooth bark. At high fire caused damage is complete and it is urgent to carry out cutting the fire site.

\section{Plant response to fire}

After the fire, environment change, and species are forced to adapt to the new conditions of his residence (Bond et al. 1996) which suggests that some of them have developed certain mechanisms that allow them to survive the trauma caused by the fire. It is known that only the most widespread species are able to colonize the environment damaged by fire, and to found a organized and identified community there (Chandler et al. 1983., Chandler et al. 1983a). In addition, it is necessary to know the factors that causes land. Fire can contribute to yield material or, in contrast, to losses in the mineral mass to such an extent that over time contributes to the overall decline in soil fertility.

Completed surveys of vegetation regeneration after the fire showed that:

- Most of the plants that appear after the fire is being developed from the 
regeneration organs (rhizomes, bulb, boxes, seeds, etc..) who were in the land even before the passage of fire, or who have been brought

- All the plants that are regenerated by vegetative process, provide new shoots during the first months after the fire, regardless the season of the year

- the period during which the greatest number of sprouting plants which are regenerated through the grain, occurs, is only the first two years after a fire, and

- a new species (regarding the boards before the fire) which appear after the fire (Trabaund, 1990) are rare.

The stability of plant communities is affected by the frequency of fire passing. When a fire appears every two or three years, there is a significant change in the dominance of certain plants (some may even fade), and therefore, in the structure of communities. It was found that changes in phyto mass is greater if the fires are more frequent and if distances between them are shorter. Under the effects of fire, phyto mass becomes weaker, which will cause a reduction in growth. All stems that are above the ground, that every time they get burned, do not have time to grow back. The recurrence of fire is important for the survival of species that reproduce only through sexual reproduction, by seeds. If the time between two successive fires, is shorter then the time required to achieve needed level of sexual maturity of plant, it may occur that some species disappear (Chandler et al.1983). Some species have developed certain survival mechanisms that enable them resistance to fire. Oak tree, due to its noncombustible crust that is both thermally insulating is an example of such mechanisms.

Plants that are regenerated by offshoots or sprouts and seeds at the same time, if having some resistance in terms of drought, can after the fire, start again to take up space. Plants that reproduce themselves only by seeds, appear much later, and their seeds remain in the soil and germinate only after the first autumn rains and in the spring of the following year. Depending on the size of the fire, there is a change of the surface layer of the soil. After the fire, significant loss of nitrogen and a slight increase of phosphorus content, appears. Due to the fire, the high temperature of the layer of soil will lead to changes in the chemical composition with the ability to change the $\mathrm{pH}$, decrease the moisture content and the loss of Microorganism at a depth up to 0.2m (Trabaund 1990., Živanović 2003). This phenomenon - destroying organisms, causes disappearing of micro rhizal fungi without whose presence nutrition of many plants and many species of trees (pine, oak, etc.) is not possible. 


\section{Dynamics of the occurrence of fire in Serbia}

Depending on the plant layers above the fire may be underground, ground (low) and the crowns of trees. According the place of appearance it belongs to the type of the open air fires.

The spread of fire is caused by the combustion of fuel quantity of new material and, for this reason, these fires represent a dynamic phenomenon. Specifically, the rate of fire spread changes over time, even in nominally fixed thresholds, such as topography and vegetation conditions and wind speed.

The occurrence of fire in Serbia is different from period to period (Živanović 2010., Ćurić et al. 2013). Figure 1 shows the number of fires in the open air during the vegetation period 2009 to 2010 . The largest number of fires in the open air, have been registered in Serbia at the beginning and at the end of the growing season, Figure 1. The figure noted that a number of fires in the second half of the growing season.

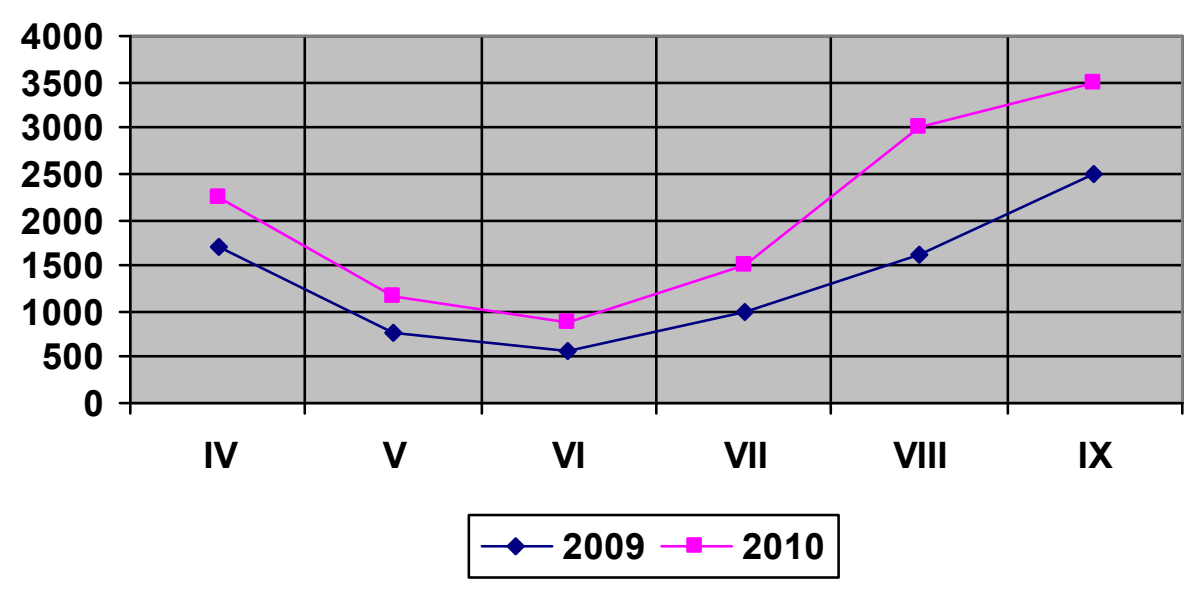

Figure 1. Number of fires in the open air during the growing season

During the period from 1990 to 2011, on the territory of Serbia, the largest area affected by fire were in 2007, (22161ha), Figure 2, which is about $0.25 \%$ of the territory of Serbia . 


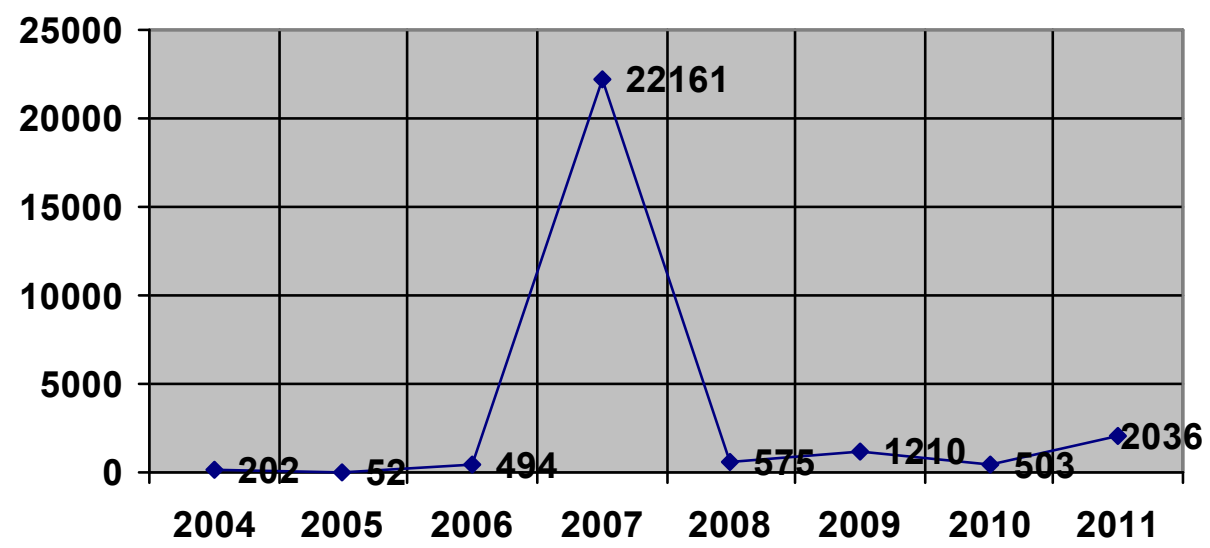

Figure 2. Burnt forest area in the period 2004-2011, on the territory of Serbia, ha (Source : " http://webrzs.stat.gov.rs/ " http://webrzs.stat.gov.rs , 2012.)

\section{Conclusion}

Monitoring the effects of fire on flora is an important factor in preventive action to protect nature Forest fires act directly or indirectly on plant life in nature. These fires encourage the process of selection among species, leading to the complete mineralization of accumulated waste and litter, naturally decrease thick dense vegetation communities and renew it. (run cycles of succession in an ecosystem). Certain plant species have developed mechanisms of biological adaptation to the effects of fire.

The incidence of fire recurrence is important for the survival of species that reproduce only by sexual reproduction. If the time between two successive fires, is shorter then the time required to achieve needed level of sexual maturity of plant, it may occur that some species disappear.

The findings on the impact of the fire effects on the vegetation behavior in nature are of great importance for determining the biological measures. Also, this information will be useful for further development and refinement of selecting, as the plants will have a certain tolerance to stress from the effects of fire. Risk reduction can be made by fire prevention and proper education of the population. 


\section{References}

Aleksić P., Krstić M., Jančić G. (2009): Forest fires - ecological and economic problem in Serbia. Botanica Serbica. vol. 33 (2), pp. 169-176.

Anonymous. (2010): Ordinance on the proclamation and protection of protected and strictly protected wild species of plants, animals and fungi, Official Gazette of the Republic of Serbia, No. 5 , Belgrade,

A n o n y mous . (2007): Register of protected areas, the Institute for Nature Conservation of Serbia, Belgrade

Banković S., Medarević M., Pantić D., Petrović N., Šljukić B., Obradović S. (2009): The Growing stock of the Republic of Serbia -state and problems, Bulletin of the Faculty of Forestry 100, pp 7-30.

Banković S., Medarević M., Pantić D., Petrović N. (2009): National Forest Inventory of the Republic of Serbia - Forest Fund of the Republic of Serbia, Ministry of Agriculture, Forestry and Water Management of the Republic of Serbia, Planeta print Belgrade, p. 244.

B ond, W J., van Wilgen, BW. (1996): Fire and Plants, p.36. London:Chapman \& Hall,

Borges, E.E.L.; Rena, A.B. Germinação de sementes. In: AGUIAR, I.B.; PIÑARODRIGUES, F.C.M.; FIGLIOLIA, M.B. (Coord.) (1993): Sementes florestais tropicais. Brasília: ABRATES, p.83-136.

B rown JK, Smith JK. (2000): Wildland fire in ecosystems: effects of fire on flora. USDA Forest Service Gen. Tech. Rep. RMRS-GTR-42-vol. 2. p. 257

Chandler C., Cheney P., Thomas P., Trabaud L., Williams D. (1983): Fire in forestry vol.I Forest Fire Behavior and Effects, USA,

Chandler C., Cheney P., Thomas P., Trabaud L., Williams D. (1983): Fire in forestry vol.II Forest Fire Management and Organization, USA,

Cochrane, M. A. (2009): Tropical Fire Ecology: Climate Change, Land Use, and Ecosystem Dynamics. New York, NY: Springer Praxis Books,.

Ćurić M., Živanović S. (2013): Dependence between Deficit and Surplus of Precipitation and Forest Fires, Disaster Advances, Vol 6(6), pp 64-69

Schwilk W D., Ackerly DD. (2001): Flammability and serotiny as strategies: correlated evolution in pines, OikosVolume 94, Issue 2, pages 326-336,

Escudero A, Barrero S, Pita JM. (1997): Effects of high temperatures and ash on seed germination of two Iberian pines (Pinus nigra ssp salzmannii, P sylvestris var iberica), Annales des Sciences Forestieres, Volume 54/ 6, pp. 553 - 562

González-Rabanal F, Casal M. (1995): Effect of high temperatures and ash on germination of ten species from gorse shrubland - Vegetatio, - volume 16 issue 1, pp 123-131

Kane JM, Varner JM, Hiers JK. (2008): The burning characteristics of southeastern oaks: Discriminating fire facilitators from fire impeders, Forest Ecology and Management, Volume 256, Issue 12, pages 2039-2045

Keeley J.E. (1987): Role of fire in seed germination of woody taxa in California chaparral, Ecology 68. pp 434-443.

Levitt, J . (1972): Responses of Plants to Environmental Stresses. Academic Press, New York 
Malanson P.G. (1997):Effects of feedbacks and seed rain on ecotone patterns, Landscape Ecology, vol 12 no 1, pp 27-38

Martin PS. (1963): The last 10,000 years; a fossil pollen record of the American Southwest, Tucson, University of Arizona Press.

Mihajlović R.E., Živanović V.S., Kovačević B., Zigar D. (2014): Influence of high environmental temperature ability of seeds from the genus of oaks (Quercus), Romanian Biotechnological Letters, Vol. 19, No. 2, pp 9248-9256

Nunez R.M, Calvo L. (2000): Effect of high temperatures on seed germination of Pinussylvestris and Pinushalepensis, Forest Ecology and Management, Volume 131, Issues 1-3, pages 183-190

Pausas G.J. (1997): Resprouting of Quercus suber in NE Spain after fire, Journal of Vegetation Science Volume 8, Issue 5, pages 703-706,

Reyes O., Casal M. (1994): Reproductive behaviour of Quercus robur related to the size and damage state of the seed, in: Universidad de Coimbra (Ed.), 2nd Conference of Forest Fire Research, vol. II, Coimbra, , pp. 1009-1018.

Reyes O., Casal M. (1995): Germination behaviour of 3 species of the genus Pinus in relation to high temperatures suffered during forest fires, Ann. Sci. For. 52. 385392

Reyes O., Casal M., Trabaud L. (1997): The influence of population, fire and time of dissemination on the germination of Betula pendula seeds, Plant Ecol. 133. 201-208.

Reyes O., Basanta M., Casal M, Díaz-Vizcaíno E. (2000): Functionating and dynamics of woody plant ecosystems in Galicia (NW Spain), in: Trabaud L. (Ed.), Life and Environment in the Mediterranean, WIT Press, Southampton, pp. 1-41.

Reyes O, Casal M. (2006): Seed germination of Quercus robur, Q. pyrenaica and Q. ilex and the effects of smoke, heat, ash and charcoal - Annals of Forest Science, afs-journal.org

Sekulić G., Dimović D., Kalmar Z., Krnajski J., Todorović N. (2012): Assessing vulnerability to climate change - Serbian, WWF (World Wide Fund for Nature), Center for the Advancement of Environment, Belgrade

Stevanović V. (1999): Red book of Serbia, Belgrade,

Stevanović MB, Janković MM. (2001): Ecology of plants with the basics of physiological ecology of plants, NNK Beograd, p. 500

Trabaund L. (1990): Jedno gledište o ekološkom pristupu problemu požara vegetacije u oblasti Sredozemlja, časopis Zaštita od požara br. 11-12, Beograd.

Valbuena L.; Tarrega R. (1998): The influence of heat and mechanical scarification on the germination capacity of Quercus pyrenaica seeds, New Forest, Volume 16, Number 2, pp. 177-183(7)

Veselinović M., Milenković S., Rakonjac Lj. (2007): Prevention of forest fires: a manual for training trainers, Institute of Forestry, Belgrade, p 104

Živanović S. (2003): Analysis of air temperature in the area Timočki region in terms of threat of forest fires, Scientific conference with international participation Ecological truth Donji Milanovac, Proc. 43-46.

Živanović S. (2010): Risk factors for forest fires, Security, Belgrade, vol 52, iss. 2, pp. $179-190$ 


\title{
ŠUMSKI POŽARI KAO FAKTOR UGROŽAVANJA BILJNIH VRSTA
}

\author{
Stanimir Živanović \\ Odeljenje za upravljanje vanrednim situacijama, Kneza Miloša 103, 11000 \\ Beograd, Srbija

\section{Rezime}

Rast i razvoj a time i rasprostanjenost biljne vrste je uslovljen nizom različitih uticaja. Biljke su sve više izložene delovanju različitih stresnih faktora. Požari u prirodi u kratkom vremenskom periodu mogu u potpunosti da unište čitave šumske komplekse sa staništima velikog biološkog diverziteta brojnih vrsta. U radu se analizira delovanje efekata požara, kao što je toplota, na biljke. Nakon požara, sredina se menja i neke vrste u zonama oštećenim požarom pojaviće se tek posle požara, neke, koje su postojale pre požara, razviće se u skladu sa novostvorenim uslovima, a neke isčeznuti posle požara.

Cilj rada je određivanje održivosti vegetacije u prirodi u uslovima požara, što je od značaja za prirodno obnavljanje i rasadničku proizvodnju. Temperature požara izazivaju nepopravljive štete u funkcijama ili na biljnim organima. Učestalost prolazaka vatre je često važnija $u$ analizi uticaja na biljne vrste, čak i od vrste i intenziteta požara. Obzirom na moguće duge sezone požara na području Srbije, kao i iskazane statističke podatke broja požara i opožarene površine, može se zaključiti da je evidentan rizik biljnih vrsta od požara, koji su sve češći na ovim prostorima.

Ključne reči: šumski požar, ugrožavanje biljnih vrsta, životna sredina, 